\title{
FACTORS ASSOCIATED WITH DENGUE FEVER PREVENTIVE PRACTICE USING THEORY OF PLANNED BEHAVIOR
}

\author{
Kanthi Devi Ayuningtyas ${ }^{1,2)}$, Setyo Sri Rahardjo3), Bhisma Murti²) \\ ${ }^{1)}$ School of Health Sciences Patria Husada Blitar \\ ${ }^{2)}$ Masters Program in Public Health, Universitas Sebelas Maret \\ 3)Faculty of Medicine, Universitas Sebelas Maret
}

\begin{abstract}
Background: Dengue fever, also known as breakbone fever, is a mosquito-borne infection that can lead to a severe flu-like illness. It is caused by four different viruses and spread by Aedes mosquitoes. There are currently no vaccines. The best method of prevention is to avoid mosquito bites. Treatment is possible if diagnosis occurs before the patient develops dengue shock syndrome (DSS) or dengue haemorrhagic fever (DHF). This study aimed to investigate factors affecting dengue fever preventive practice using theory of planned behavior, using theory of planned behavior.
\end{abstract}

Subjects and Method: A cross sectional study was conducted in 8 sub-districts in Sukoharjo, Central Java, from May 7 to July 8, 2018. A sample of 200 study subjects was selected for this study by random sampling. The dependent variable was dengue fever preventive practice. The independent variables were intention, self-efficacy, perceived seriousness, attitude, and education. The data were collected by questionnaire and analyzed by path analysis.

Results: Dengue fever preventive practice was directly and positively affected by intention $(b=0.62 ; 95 \% \mathrm{CI}=0.45$ to $0.79 ; \mathrm{p}<0.001)$, self-efficacy $(b=0.13 ; 95 \%$ $\mathrm{CI}=0.01$ to $0.25 ; \mathrm{p}=0.043)$, and perceived seriousness $(\mathrm{b}=0.31 ; 95 \% \mathrm{CI}=-0.05$ to $0.67 ; \mathrm{p}=0.091)$. Dengue fever preventive practice was indirectly affected by attitude and education.

Conclusion: Dengue fever preventive practice is directly and positively affected by intention, self-efficacy, and perceived seriousness. It is indirectly affected by attitude and education.

Keywords: dengue fever, preventive practice, Theory of Planned Behavior

\section{Correspondence:}

Kanthi Devi Ayuningtyas. School of Health Sciences Patria Husada, Blitar, Jl. Sudanco Supriyadi No 168, Blitar, East Java.

Email: kanthideviayuningtyas@gmail.com. Mobile: 08125266956. 